EDITORIAL

\title{
Addressing Racism as a Public Health Crisis in Ohio
}

\section{Amy Ferketich}

The Ohio State University, College of Public Health, Columbus, $\mathrm{OH}$

Welcome all new and returning readers to this issue of the Ohio Journal of Public Health (OJPH). This is the first special issue that $O J P H$ has published outside of the regular cycle, and it is devoted to the public health crisis of racism that Ohio and other states continue to face. Public health scholars have for years examined the impact racism has on community well-being and health outcomes. ${ }^{1}$ Structural racism and discrimination lead to many negative health outcomes in the Black community, including, but not limited to, higher rates of infant and maternal mortality, higher rates of hypertension and stroke, lower life expectancy, and mental health impairment. No one sector in society is solely responsible for these inequities; rather, multiple systems, including education, housing, criminal justice, health care, and others, act synergistically to create environments that literally kill people. ${ }^{2}$

When the COVID-19 pandemic struck, the devastating effects of long-standing, deep-seated, structural racism on communities of color were observed by all. News media, ${ }^{3}$ government organizations, ${ }^{4}$ and academic scholars ${ }^{5}$ all noted the significant racial and ethnic disparities in COVID-19 incidence and mortality. Indeed, one of the largest studies to date on COVID-19 disparities concluded that these inequities are due to structural determinants, including limited employment opportunities, health care access, and housing quality that disadvantage Black and Hispanic adults. ${ }^{5}$

At the same time COVID-19 was unleashing its destruction and causing disparate effects on Black, Hispanic, and other marginalized communities, the world witnessed the cruel and unjustified killings of George Floyd, Breonna Taylor, and others at the hands of law enforcement. While these killings sparked outrage and weeks of protests across the country, they were certainly not the first to occur. Many will remember the 2014 killing of 12-year-old Tamir Rice by Cleveland police. Unfortunately, these senseless deaths continue, as we witnessed very recently in Columbus with the killing of Casey Goodson Jr. by a law enforcement agent.

While these tragedies were unfolding last spring, many communities in Ohio started to regard racism as a public health crisis (or, to declare racism a public health crisis). To date, 6 counties and 11 cities have made such declarations. ${ }^{6}$ Governor DeWine also declared racism a public health crisis during his presentation of the report from the COVID-19 Minority Health Strike Force. ${ }^{7}$ How should we respond to these declarations? As public health professionals, we know that any response requires implementing evidence-based practices, educating policymakers and the public about how they can promote healthier communities, and conducting research on ways to dismantle the multilevel barriers to health equity. In sum, we must diligently work toward the goal that Robert Jennings, Past President of the Ohio Public Health Association, set out in his June 2020 statement: "Let us together tear down the oppressive walls of institutional racism and begin building a better community where all have an equitable opportunity to freely breathe."8

This Editorial Board of $O J P H$ envisioned this special issue early in June as one way to respond to the dual crises affecting Black people in Ohio. Conversations about the problems and solutions need to occur prior to building the healthier communities that Mr. Jennings spoke of in his statement. Our call for papers prompted outstanding contributions from health equity scholars and public health practitioners around the state. I am so proud that my public health colleagues around the state were quick to act and submit papers that were responsive to the call.

This issue features their work, including 2 research papers, a commentary, and an Op-Ed. The paper by Steinman, PriceSpratlen, and Browning presents data from the 2019 Ohio Medicaid Assessment Survey, which is one of the 
largest state health surveys in the country. They report the prevalence of, and factors associated with, adult proxyreported perceived racial discrimination of youth in Ohio. The results suggest that perceived discrimination is higher among Black youth who are older, from higher income families, and from rural communities. Additionally, perceived discrimination is associated with poor mental health outcomes. These results indicate that interventions to eliminate discrimination should target youth, as negative health effects may emerge at an early age. The other research paper in this issue, by Gotto, Morello, and Michie examines health care provider knowledge of racism and how such awareness may impact their communication with their Black pregnant patients. While this study was terminated early because of COVID-19, the preliminary findings suggest that a provider's recognition that racism impacts birth outcomes may influence their communication style with patients.

The commentary in this issue, authored by Nawaz and colleagues, promotes a more comprehensive framework for studying the multidimensional constructs of racism, including systemic racism, interpersonal racism, and internalized racism. The expanded model provides additional measures that can be assessed to determine if community-level interventions are having any impact on reducing inequities. Finally, Singer uses a legal lens in her Op-Ed to outline the many ways in which the COVID-19 pandemic negatively impacted low-income communities. She describes the effects of business closures early on, decisions to re-open states earlier than recommended, and the segment of the population that was not eligible for enhanced unemployment benefits. Combined, these factors have the potential to further widen inequities due to COVID-19.

This issue again features a cover design by Whitney Baxter and Gad Owusu, undergraduate students in the Department of Design at The Ohio State University. During a semester that was extra stressful due to surges in COVID-19 cases on college campuses in Ohio, Whitney and Gad carved out time to create a design that embraces the theme of this issue. This issue is also my penultimate as Editor. I am thrilled to announce that Professor Sheryl Chatfield, of Kent State University, will be the next Editor of OJPH. As a current Editorial Board member, author of several papers in previous OJPH issues, and public health educator, scholar, and professional, she is well-positioned to take the reins after June 2021. Until then, I will work with her on a smooth transition. And, I will continue to advocate for the important work that the Ohio Public Health Association does on a daily basis to be the "voice" of public health in Ohio.

\section{REFERENCES}

1. Williams DR, Lawrence JA, Davis BA. Racism and health: evidence and needed research. Annu Rev Public Health. 2019;40:105-125. https://doi.org/10.1146/annurev-publhealth-040218-043750

2. Reskin B. The race discrimination system. Annu Rev Sociol. 2012;38:17-35.

https://doi.org/10.1146/annurev-soc-071811-145508

3. Oppel RA, Gebeloff R, Lai KKR, Wright W, Smith M. The fullest look yet at the racial inequity of coronavirus. The New York Times. July 5, 2020. Accessed December 11, 2020.

https://www.nytimes.com/interactive/2020/07/05/us/coronavirus-latinos-african-americans-cdc-data.html?

action $=$ click\&module $=$ RelatedLinks\&pgtype $=$ Article

4. Centers for Disease Control and Prevention. Health equity considerations and racial and ethnic minority groups. Published July 24 , 2020. Updated 2020. Accessed December 11, 2020.

https://www.cdc.gov/coronavirus/2019-ncov/community/health-equity/race-ethnicity.html

5. Ogedegbe G, Ravenell J, Adhikari S, et al. Assessment of racial/ethnic disparities in hospitalization and mortality in patients with COVID-19 in New York City. JAMA Netw Open. 2020;3(12):e2026881.

https://doi.org/10.1001/jamanetworkopen.2020.26881

6. Walliser-Wejebe M. Communities across the state declare racism as a public health crisis, the state considers it. Greater Ohio Policy Center. 2020. Accessed December 11, 2020.

https://www.greaterohio.org/blog/2020/7/16/communities-across-the-state-declare-racism-as-a-public-health-crisis-the-stateconsiders-it?

7. Chow A. DeWine says racism is a public health crisis. The Statehouse News Bureau. August 142020 . Accessed December 11, 2020. https://www.wyso.org/news/2020-08-14/dewine-says-racism-is-a-public-health-crisis

8. Jennings R. OPHA statement on the death of George Floyd. Published June 3, 2020. Updated 2020. Accessed December 11, 2020. https://ohiopha.org/opha-statement-on-the-death-of-george-floyd/ 